\title{
Environmental Violation Fines Growth in the Northern Region of Santa Catarina State, Brazil
}

\author{
Jessica da Silva Costa $^{1}$ (D), Raquel Valério de Sousa ${ }^{1}$ (D), Veraldo Liesenberg ${ }^{1}$ \\ ${ }^{1}$ Centro de Ciências Agroveterinárias, Universidade do Estado de Santa Catarina, Lages/SC, Brasil
}

\begin{abstract}
This study aimed to diagnose the environmental infractions that occurred in the northern region of Santa Catarina State (Southern Brazil). The environmental infractions were classified by category and by violation activities concerning the hydrographic regions of Canoinhas Plateau and Baixada Norte from 2014 to 2018 to assess the growth and causes of a diagnosis regarding the environmental damages occurrences. Results indicated that the major illegal environmental practices registered in both region are related to environmental violations regarding the damage caused in native vegetation, and these damages are caused without authorization of the competent environmental authority. In addition, it was also important to note the activity of maintaining birds in captivity and of functioning of potentially pollutant activities or establishments that do not have a license of the competent regional environmental agencies. Therefore, efforts from the Environmental Policy should be directed to implement a forest monitoring system using remote sensing technology apart from starting a stronger cooperation with municipal authorities from Santa Catarina State by promoting Environmental Monitoring Programs (EMP).
\end{abstract}

Keywords: environmental policy, environmental crime, environmental legislation. 


\section{INTRODUCTION}

As humanity increases its demand to interfere with nature to satisfy their needs and desires, it has been seen that conflicts arise regarding the use of spaces and resources (Azevedo-Santos et al., 2017). The human being is responsible for transforming nature, causing severe and irreversible changes in the environment, such as the exploitation of natural resources that has been causing the loss of biodiversity on Earth (Freitas et al., 2017).

In this sense, environmental inspection represents an important tool to prevent, combat and control practices that cause environmental degradation, and it guides the rational use of natural resources (Nicolle \& Leroy 2017; Alarcon et al., 2015; Arima et al., 2014). According to Instituto Brasileiro do Meio Ambiente e Recursos Naturais (IBAMA, 2018), environmental inspection aims to change people's beahaviour by coercion and imposing pecuniary and non-pecuniary sanctions to induce behavioral compliance and social behavior to rules and exploring dissuasion practices of environmental damage.

In practice, it consists of responsabilities of the Public Power to supervise the conducts of those individuals who are potential or effective polluters and also users of natural resources, in order to ensure the preservation of the environment for the community (Chagas et al., 2015). Concerning environmental inspection, it can be highlighted the performance of the Environmental Military Police (in Portuguese Polícia Militar Ambiental - PMA), which monitors, prevents and curbs environmental violations through administrative procedures by analyzing and judging infractions committed against the environment.

For Rambusch \& Bender (2011), the PMA was namely as the legitimation of the State to monitor, prevent and curb any and all conducts that generate environmental damage, however, the PMA must be properly equipped with instruments capable of avoiding and repressing infractions against the environment. Such organization, ensures consequently, the respect for the law and the quality of life for present and future generations.

In Santa Catarina State, located in Southern Brazil, the PMA is an integral body of the State Environmental System and it is responsible for implementing environmental inspection of the infractions related to flora, fauna, pollution, urban planning and administration, which occurs throughout the entire region (Sothe \& Goetten, 2017). The performance of the PMA could be described as finding the environmental infraction, in whichthe infraction notice takes place until its judgment (Schneider et al., 2018).

However, due to reduced number of environmental policy officers and computational resources, the PMA have few sources to pay attention to such occurrences. The better understanding of the nature of the environmental infractions, their causes and reasons develops knowledge for conservation policy establishments and their mitigations. Additionally, it also allows to study the impacts of such occurrences on the environment and their respective populations. Therefore, studies related to both spatial and temporal distribution of environmental violations are still necessary. In this way, the objective of this study was to perform an overall diagnosis of the environmental infractions recorded in the northern region of Santa Catarina State by the PMA from 2014 to 2018. In addition, it was also important to characterize the major illegal environmental practices registered in the Northern Region.

\section{MATERIAL AND METHODS}

In this article, it was studied the environmental infractions recorded by the PMA from the northern Santa Catarina, which consists of two hydrographic regions, the regions of Canoinhas Plateau and Baixada Norte, encompassing 19 and 15 municipalities and an area of $11,058 \mathrm{~km}^{2}$ and $5,138 \mathrm{~km}^{2}$, respectively (Figure 1).

According to the IBGE (2018), the northern region of Santa Catarina State has reached a population of 1,222,730 inhabitants in 2010 and a population density of 82.0 inhabitants per $\mathrm{km}^{-2}$. According to the Köppen classification, the Canoinhas plateau has humid subtropical climate, in other words, mesothermal climates, with mild summers and moderate winter (Cfb). Whereas, the Baixada Norte region presents two climate systems, $\mathrm{Cfb}$ and humid subtropical climate with hot summers (Cfa). Cfa climate is characterized by an average temperature higher than $10^{\circ} \mathrm{C}$ in the coldest month and higher than $22{ }^{\circ} \mathrm{C}$ in the hottest 


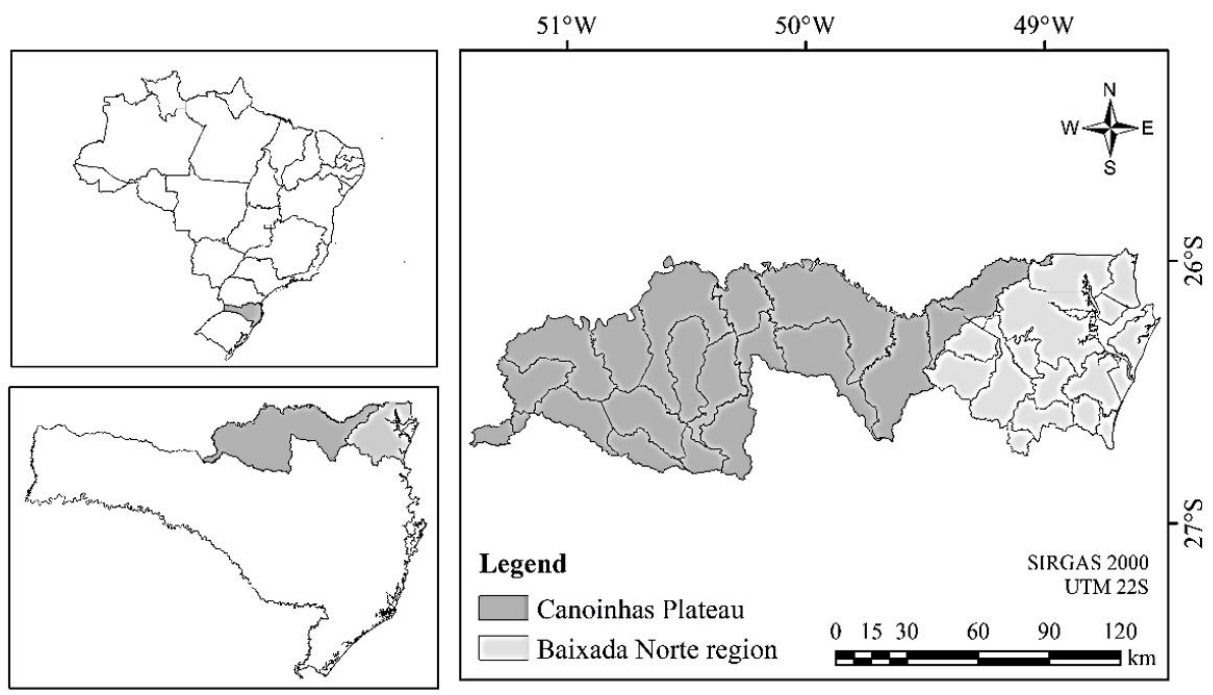

Figure 1. Study area in Brazil, Santa Catarina State, and North region of the Santa Catarina State. Black lines indicate administrative boundaries.

month. $\mathrm{Cfb}$ is characterized by average temperatures lower than $22{ }^{\circ} \mathrm{C}$ in the hottest month.

The entire northern region has a very rugged terrain, with formations of plains, plateaus and mountains, and the minimum altitude is three meters above sea level at Joinville municipality and maximum altitude is 925 meters above sea level at Itaiópolis municipality (SEBRAE, 2013). The northern region of the Santa Catarina State is characterized by Dense Ombrophilous Forest, Mixed Ombrophilous Forest (MOF) and Plateau Grassland Fields, with several species of invertebrates, amphibians, reptiles, birds and mammals (Schneider et al., 2018; Andrade et al., 2015).

The data for environmental infractions analysis were acquired through continuous consultation of the GAIA online system. In Portuguese, GAIA is the abbreviation for Gestão e Acompanhamento de Infrações Ambientais. The acronym stands for Management and Monitoring System of Environmental Violations which aims to record all the environmental administrative processes within the framework of the Santa Catarina State Environmental Foundation (Instituto do Meio Ambiente em Santa Catarina - IMA) and PMA, in order to facilitate its consultation, organization and control (Rosa, 2015). In this way, by searching the online system, a total of 3,440 processes were extracted in the studied region from 2014 to 2018. In this period, regarding the GAIA system, 482, 675, 602, 872 and 809 environmental processes were recorded, respectively. However, due to limited time to perform the analysis of all the processes recorded in these years, the sampling of a number of processes, that is representative of the characteristics of the region, was selected.

To determine the number of representative processes, the minimum sample size was calculated, according to Equations (1) and (2), proposed by Barbetta (2011).

$\mathrm{no}=\frac{1}{\mathrm{E}^{2}}$

$\mathrm{n}=\frac{\mathrm{N}^{*} \text { no }}{\mathrm{N}+\mathrm{no}}$

Being $\mathrm{n}_{0}$ the first approximation for the sample size, with a tolerable sample error (E) of $8 \%$, that is, how much a mistake may be tolerated regarding the evaluation of environmental processes. This margin of error of the sample was selected randomly. This value allowed a number of representative processes for the study area. Small values would indicate an increase processes to be analyzed, what is usually not feasible. On the other hand, high values would reduce the number of processes and increasing may associated with sampling errors.

The final value of the sample size (n) considers the first approximation for the sample size $\left(\mathrm{n}_{0}\right)$ and the total number of environmental processes $(\mathrm{N})$. Thus, the calculated number of samples to represent each year was 
in order 117, 125, 122, 156 and 156 for 2014, 2015, 2016, 2017 and 2018 respectively, which correspond to the amount of processes that has been analyzed in this study.

To perform the analyses of environmental violations in the studied regions, the environmental crimes were divided into categories and activities. Each activity is related with the articles from the Brazilian Decree no. 6,514, on July 22, 2008 (Brasil, 2008), which describes the administrative violations committed against the environment. Table 1 shows this division, in which, in the category "Flora", there are articles about crimes committed against flora; regarding the category "Fauna", there are articles concerning enrionmental violations against fauna; in "Pollution", articles reporting pollution crimes; and in "Others", there are articles that do not fit in any of the above mentioned categories.

The environmental processes obtained through the GAIA system were used to perform graphs in columns in order to perform the evolutionary analysis of the environmental violations recorded from 2014 to 2018. Tables and graphics were generated from the quantification of the data obtained from the processes analyzed in the studied period. The maps containing the spatial distribution of the environmental infractions were performed taking into account the geographic coordinates reported in the processes.

\section{RESULTS AND DISCUSSION}

According to the representative samples of the environmental administrative processes in the northern Santa Catarina State from 2014 to 2018 , it was possible to analyze their data, provided by the GAIA system (Figure 2). In Figure 2, the violations by categories is ilustrated, in other words, categories which were defined in the study with its evolutionary trend in the period of five years from 2014 to 2018 . In this period, a total of 676 processes were analyzed, being yearly divided in $117,125,122,156$, and finaly 156 processes.

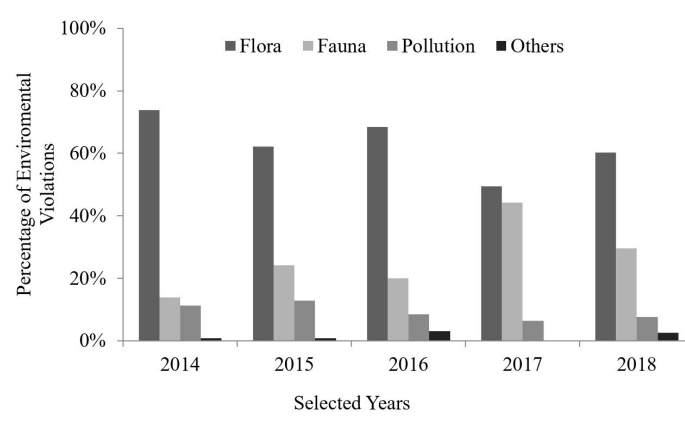

Figure 2. Growth of environmental violations in the northern region of Santa Catarina State on different categorizations.

Table 1. Categories and activities related to the articles of environmental crimes according to Brazilian FD no. 6,514, of July 22, 2008 (Brasil, 2008).

Category $\quad$ Activities $\quad$ Article

$\begin{array}{ll}\text { To damage native vegetation without license } & 50\end{array}$

To destroy native vegetation reaching Permanent Preservation Area (PPA) without authorization 43

To harvest trees without permission

44

Flora To turn wood into coal for industrial purposes without a license 46

To store wood of native origin or acquire coal without Forest Origin Document (DOF) 47

$\begin{array}{ll}\text { To prevent natural regeneration of forests } & 48\end{array}$

To use a chainsaw to cut vegetation without license $\quad 57$

To maintain fauna species in captivity without authorization 24

$\begin{array}{ll}\text { Prohibited fishing } & 35\end{array}$

$\begin{array}{llr}\text { Fauna } & \text { To exercise fishing without a license } & 35\end{array}$

To fish using prohibited gear $\quad 36$

$\begin{array}{ll}\text { To pollute causing significant destruction of biodiversity } & 61\end{array}$

\begin{tabular}{lll}
\multirow{2}{*}{ Pollution } & To launch oily substance in disagreement with the established requirements & 62 \\
\cline { 2 - 3 } & To store toxic substance & 64
\end{tabular}

To build potentially polluting establishments without license 66

To extract minerals without the competent permission 63

To fail to enroll in the Federal Technical Register $\quad 76$

Others To hinder the action of public authorities in the exercise of environmental inspection $\quad 77$

$\begin{array}{ll}\text { To break an embargo } & 79\end{array}$ 
For all the years, the category with the largest number of environmental violations was Flora, consisting of $73.91 \%$ in $2014,62.10 \%$ in 2015 and $68.46 \%$ in 2016 , $49.36 \%$ in 2017 and $60.26 \%$ in 2018 regarding the total of analyzed infractions in both study areas. Figure $3 \mathrm{a}$ shows the spatial distribution of all environmental violations presented $85,77,79,77$ and 94 processes from 2014 to 2018 , respectively, and it is important to highlight that this category has been the most registered environmental administrative processes within selected period. This can be explained by the large number of restrictions in this category as shown in Table 1, as well as, the availability of abundant forest coverage in the region (Vibrans et al., 2013).

According to some mapping initiatives reported by Vibrans et al. (2013), there were large forest remnants with relevant diversity of flora species in the region.
Therefore, for example, it is more common to observe deforested areas than potentially polluted companies which are not fulfilling their responsabilities under environmental license.

However, it is important to note that the majority of the environmental administrative processes are based on deletions that are made anonymously and rarely by in-situ surveillance operations performed randomly by car and helicopter. This position reinforce the importance of having a monitoring system based on remote sensing images. Such initiatives are already implemented in other Brazilian biomes (Nicolle \& Leroy 2017; Watanabe et al., 2018; Warren-Thomas et al., 2018; Reiche et al., 2018; Bouvet et al., 2018; Silva et al., 2018; Grecchi et al., 2017; Carvalho et al., 2017). Thus, based on the scores presented in Figure 3, it could be demonstrated that the categories related to Fauna,

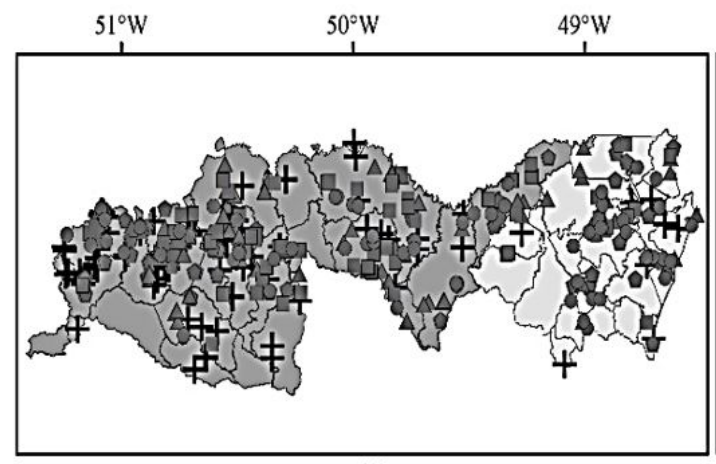

(A)

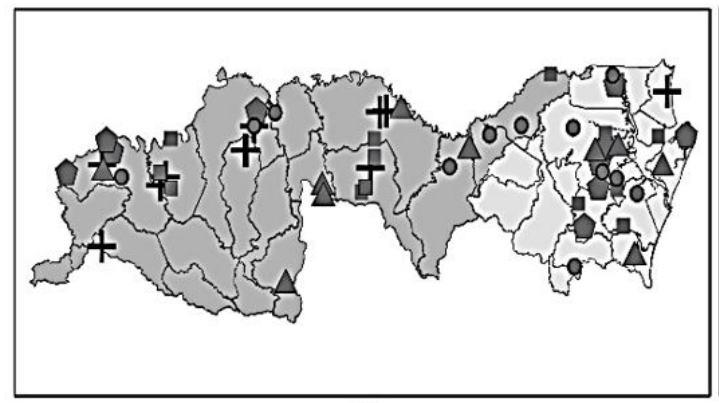

(C)

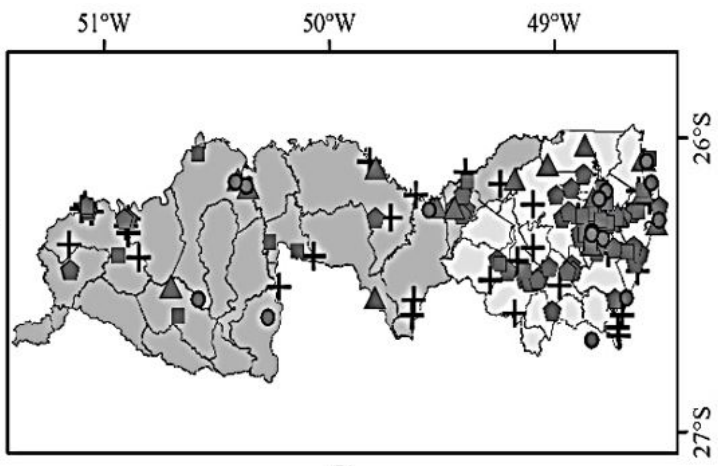

(B)

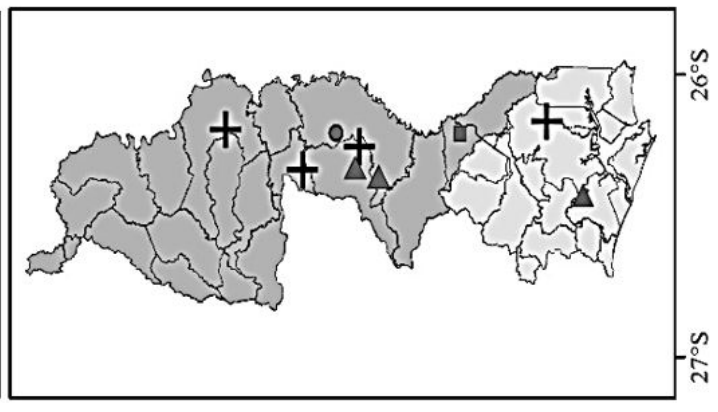

(D)

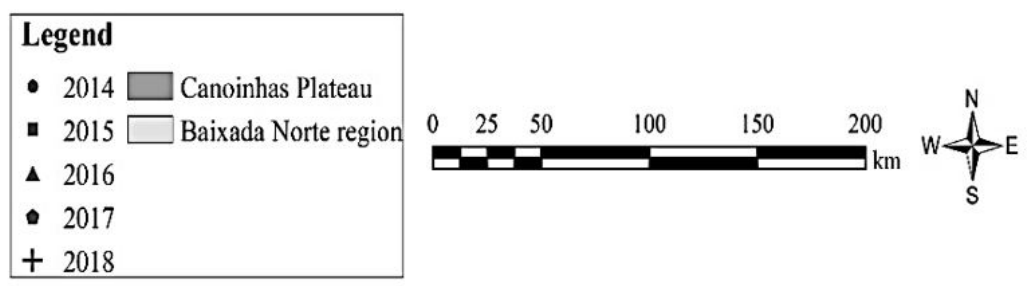

Figure 3. Spatial distribution of the environmental violations against Flora (A), Fauna (B), Pollution (C) and Others (D). 
Pollution and Others had a number of environmental violations smaller than Flora. However, this does not mean that these violations are not practiced. However, the visual impact of deforestation induces local inhabitants to report the occurrence anonymously.

The Canoinhas Plateau had 77 processes in 2014, 88 processes in 2015, 79 in 2016, 81 processes in 2017 and 120 in 2018. The Baixada Norte accounted for 40 processes in 2014, 37 in 2015, 43 in 2016, 75 in 2017 and 36 in 2018. The Canoinhas Plateau has a greater number of environmental violations than Baixada Norte regarding the five studied years, which can be explained by the amount of infraction notices recorded by the PMA regarding the Flora category, which was greater in Canoinhas Plateau in the studied years. Additionally, the area of Canoinhas Plateau $\left(11,058 \mathrm{~km}^{2}\right)$ is almost twice as large as the area of Baixada Norte $\left(5,138 \mathrm{~km}^{2}\right)$. Generally speaking, agricultural activity is substantially relevant in Canoinhas Plateau, resulting mostly in illegal logging followed by deforestation in order to increase land for farming in a smaller scale (Garrett et al., 2018).

The Baixada Norte presented a greater amount of environmental violations concerning the Fauna category, especially regarding the maintainance of wild birds in captivity, that is, a very expressive activity in the region. The northern region presented $16,30,26,69$, and 46 violations against fauna in 2014, 2015, 2016, 2017 and 2018, respectively. According to Figure $3 \mathrm{~b}$, the distribution of environmental violations in the last five years of analysis was more concentrated in Baixada Norte, mainly in the municipality of Joinville. In this region, the habit of maintaining wild animals in captivity still exists, that is, an activity that stimulates illegal trades in the region, resulting in the reduction and extinction of native species. Joinville is also the most populated city in Santa Catarina State due to the large number of industries and services, in other words, providing working opportunities. The IBGE (2018) accounted for 515.288 inhabitants by the Census conducted in 2010. According to the estimates made by IBGE, it could be accounted for more than 590.000 inhabitants in Joinville in 2018.

From 2014 to 2018, 412 administrative processes with environmental damage against flora were recorded, with 85 in 2014, 77 in 2015, 79 in 2016, 77 in 2017 and in 2018, 94 processes. Table 2 shows a summary of all activities included in the articles of the Federal Decree (FD) no. 6,514/08 (Brasil, 2008) that were found in the processes. According to article 50 of this Decree, which refers to activites associated with the damage to native vegetation without approval of environmental authorities, is mainly related with the removal of vegetation to perform agricultural activities, or livestock activity, that is, turning areas into pasture. On the other hand, the index connected to native vegetation damage decreased throughout the years, which might have occurred due to the increase in monitoring this activity, our due to the decrease of PMA surveillance, or even owing to the subsequent lack of records in GAIA system. Although some local initiatives have been made in the region using high spatial resolution images (Piazza et al., 2016a,b; Sothe et al., 2017), this result reinforces the importance of the large-scale remote sensing based observation system to monitor deforestation.

According to the article 47, its activity refers to the storage of native wood without the Forest Origin Document (in Portuguese Documento de Origem Florestal - DOF), occurrying frequentely for illegal trade in wood. The records of this activity obtained an expressive increase throughout the three first studied years (2014-2016), and according to these results, monitoring initiatives increased regarding this activity in the northern region of Santa Catarina State. As a result, 2017 and 2018 recorded a smaller number of infractions in this category.

The activity under article 44 referring to the illegal logging is mainly related to the illegal marketing in wood and charcoal, which is increasing substantially when compared to the regenerative capacity of forests, and is also related with the population expansion, unfortunately ending up removing native trees or even endangered trees for housing construction.

From 2014 to 2018, 187 administrative processes were recorded with environmental damage against the fauna. Table 2 shows the number of activities under the articles of FD no. 6,514/08 (Brasil, 2008) that were found in the processes related to Fauna. In the same time frame, 130 environmental infractions were recorded referring to the activity under article 24 , related to the maintenance of captive birds. Within a certain time frame from 2014 to 2018, this activity accounted for $63 \%, 67 \%, 58 \%, 84 \%$, and $59 \%$ respectively, when 
Table 2. Environmental violations commited against Flora, Fauna, as well as, Pollution and Others sources according to the Brazilian FD n. 6,514, on July 22, 2008 (Brasil, 2008).

\begin{tabular}{|c|c|c|c|c|c|c|}
\hline Category & Article & 2014 & 2015 & 2016 & 2017 & 2018 \\
\hline \multirow{8}{*}{ Flora } & 43 & $11(13 \%)$ & $11(14 \%)$ & $9(11 \%)$ & $13(17 \%)$ & $11(12 \%)$ \\
\hline & 44 & $13(15 \%)$ & $10(13 \%)$ & $14(18 \%)$ & $8(11 \%)$ & $19(20 \%)$ \\
\hline & 46 & $2(3 \%)$ & $3(4 \%)$ & $1(1 \%)$ & $1(1 \%)$ & $0(0 \%)$ \\
\hline & 47 & $13(15 \%)$ & $13(17 \%)$ & $17(21 \%)$ & $14(18 \%)$ & $15(16 \%)$ \\
\hline & 48 & $0(0 \%)$ & $1(1 \%)$ & $2(3 \%)$ & $4(5 \%)$ & $3(3 \%)$ \\
\hline & 50 & $44(51 \%)$ & $38(50 \%)$ & $34(43 \%)$ & 37 (48\%) & $43(46 \%)$ \\
\hline & 57 & $2(3 \%)$ & $1(1 \%)$ & $2(3 \%)$ & $0(0 \%)$ & $3(3 \%)$ \\
\hline & Total & $85(100 \%)$ & $77(100 \%)$ & $79(100 \%)$ & $77(100 \%)$ & $94(100 \%)$ \\
\hline \multirow{5}{*}{ Fauna } & 24 & $10(63 \%)$ & $20(67 \%)$ & $15(58 \%)$ & $58(84 \%)$ & 27 (59\%) \\
\hline & 35 & $3(18 \%)$ & $7(23 \%)$ & $9(34 \%)$ & $8(12 \%)$ & $18(39 \%)$ \\
\hline & 36 & $1(6 \%)$ & $0(0 \%)$ & $0(0 \%)$ & $0(0 \%)$ & $0(0 \%)$ \\
\hline & 37 & $2(13 \%)$ & $3(10 \%)$ & $2(8 \%)$ & $3(4 \%)$ & $1(2 \%)$ \\
\hline & Total & $16(100 \%)$ & $30(100 \%)$ & $26(100 \%)$ & $69(100 \%)$ & $46(100 \%)$ \\
\hline \multirow{5}{*}{ Pollution } & 61 & $1(8 \%)$ & $0(0 \%)$ & $0(0 \%)$ & $1(10 \%)$ & $0(0 \%)$ \\
\hline & 62 & $3(23 \%)$ & $1(6 \%)$ & $1(9 \%)$ & $5(50 \%)$ & $2(17 \%)$ \\
\hline & 64 & $2(15 \%)$ & $0(0 \%)$ & $0(0 \%)$ & $0(0 \%)$ & $0(0 \%)$ \\
\hline & 66 & $7(54 \%)$ & $15(94 \%)$ & $10(91 \%)$ & $4(40 \%)$ & $10(83 \%)$ \\
\hline & Total & $13(100 \%)$ & $16(100 \%)$ & $11(100 \%)$ & $10(100 \%)$ & $12(100 \%)$ \\
\hline \multirow{5}{*}{ Others } & 63 & $0(0 \%)$ & $1(50 \%)$ & $1(17 \%)$ & $0(0 \%)$ & $0(0 \%)$ \\
\hline & 76 & $0(0 \%)$ & $0(0 \%)$ & $3(50 \%)$ & $0(0 \%)$ & $1(25 \%)$ \\
\hline & 77 & $1(33 \%)$ & $0(0 \%)$ & $0(0 \%)$ & $0(0 \%)$ & $0(0 \%)$ \\
\hline & 79 & $2(67 \%)$ & $1(50 \%)$ & $2(33 \%)$ & $0(0 \%)$ & $3(75 \%)$ \\
\hline & Total & $3(100 \%)$ & $2(100 \%)$ & $6(100 \%)$ & $0(100 \%)$ & $4(100 \%)$ \\
\hline
\end{tabular}

compared to other activities against fauna. These results show an oscillation in the amount of recorded violations regarding this activity, so it is important to require more control from PMA to reduce such type of environmental infractions.

The environmental infractions regarding illegal fishing activities under article 35 increased throughout the five studied years in the region; this activity is mainly related with fishing during the closed season. The closed season is a measure that aims to protect the aquatic organisms during the most critical stages of their life cycles, such as breeding or growing season.

From 2014 to 2018, 62 administrative processes were recorded with environmental damage in Pollution category. The northern region presented in order 13,16,11, 10 and 12 pollution violations from 2014 to 2018, respectively. Figure 3c shows all environmental violations against pollution analyzed from 2014 to 2018, in the two selected study areas. Regarding the number of environmental violations of the Pollution category, the municipality of Joinville, presents in Baixada Norte, indicated a greater number of violations compared with other municipalities in the region. This municipality consisted of a large industrial pole including potentially polluting establishments without a license from competent environmental body. However, it is important to highlight that IMA and PMA are unable to promote intensive supervision on the industries regarding to the pollution violations in both air and water levels. In general, this responsibility is provided to the local goverments that should promote frequent monitoring (Simonassi et al., 2010; Pereira \& Röring, 2016; Santos et al., 2018). According to Kelly \& Fussell (2015) and Sîrbu et al. (2015), pollution was considered a major environmental risk factor in the incidence and progression of some diseases.

Table 2 also shows the environmental violations regarding potentially pollutant industrial activities, under article 66 of FD no. 6,514/08 (Brasil, 2008) from 2014 to 2015 , and it could be noted a substantial growth on $40 \%$ of recorded violations, which can be explained by increaseing in effectiveness in the surveillance of this activity or by developing this type 
of activity in the northern region of Santa Catarina State. In some analyzed documents regarding the recorded environmental violations, companies did not have licenses due to lack of knowledge, that is, for not knowing whether or not theiy needed an environmental license, or due to limited financial means for covering licensing expenses.

In years 2014 to 2018, fifteen administrative processes were recorded with environmental damage in Others category (Figure 3d; Table 2). By analyzing this category from 2014 to 2018, there were few activities that could fit in it. In summary, in 2014, there was a violation regarding the activity under article 77 on hindering public authorities on inspection activity. In 2015, there was one environmental violation regarding the activity under article 63 concerning extracting minerals, however, in 2016, three infractions were recorded referring to the activity included in article 76 , but not being registered in the Federal Technical Register, which is an instrument used to ensure environmental control and to monitor potentially pollutant activities that use natural resources. In 2018, three infractions were related to article 79 .

\section{FINAL REMARKS AND RECOMENDATIONS}

The results showed that the PMA efforts should act directely to fight the environmental violations regarding the damage to native vegetation without authorization. A monitoring system based on remote sensing data is recommended on an annual basis. Additionally, efforts are also necessary to fight against the maintenance of captive birds and the construction of potentially pollutant establishments. The most recorded activities were related to Flora, Fauna and Pollution categories, respectively, performed in the five analyzed years.

The category that registered the most environmental violations in the five studied years was Flora, which could be explained by percentual of forest coverage distributed in fragments with great diversity of flora species in these regions. Once again, deforested areas are the most common practice to notice. However, the number of violations recorded in Flora category is related with the monitoring operations performed by the PMA, which does not mean that categories of violations consisting of lower amounts than Flora category are less practiced. This indicates the need for increased PMA monitoring regarding the categories of violations with fewer records. Efforts performed by introducing both air and water quality monitoring initiatives in association with the State and municipal governments are strongly recommended.

\section{SUBMISSION STATUS}

Received: 6 jun., 2019

Accepted: 3 nov., 2019

\section{CORRESPONDENCE TO}

\section{Jessica da Silva Costa}

Laboratório de Geoprocessamento, Programa de Pós-graduação em Engenharia Florestal, Departamento de Engenharia Florestal, Universidade do Estado de Santa Catarina UDESC, Avenida Luiz de Camões, 2090, Bairro Conta Dinheiro, CEP 88520-000, Lages, SC, Brasil

e-mail: jessica.dsilvacosta@gmail.com

\section{REFERENCES}

Alarcon GG, Ayanu Y, Fantini AC, Farley J, Schmitt AS Fo, Koellner T. Weakening the Brazilian legislation for forest conservation has severe impacts for ecosystem services in the atlantic southern forest. Land Use Policy 2015; 47: 1-11. http://dx.doi.org/10.1016/j.landusepol.2015.03.011.

Andrade BO, Koch C, Boldrini II, Vélez-Martin E, Hasenack H, Hermann JM et al. Grassland degradation and restoration: A conceptual framework of stages and thresholds illustrated by Southern Brazilian grasslands. Natureza \& Conservação 2015; 13(2): 95-104. http:// dx.doi.org/10.1016/j.ncon.2015.08.002.

Arima EY, Barreto P, Araújo E, Soares-Filho B. Public policies can reduce tropical deforestation: lessons and challenges from Brazil. Land Use Policy 2014; 41: 465473. http://dx.doi.org/10.1016/j.landusepol.2014.06.026.

Azevedo-Santos VM, Fearnside PM, Oliveira CS, Padial AA, Pelicice FM, Lima DP et al. Removing the abyss between conservation science and policy decisions in Brazil. Biodiversity and Conservation 2017; 26(7): 17451752. http://dx.doi.org/10.1007/s10531-017-1316-x.

Barbetta PA. Estatística aplicada às ciências sociais. 7. ed. Florianópolis: Ed. UFSC; 2011. 320 p.

Bouvet A, Mermoz S, Ballère M, Koleck T, Le Toan T. Use of the SAR shadowing effect for deforestation detection 
with Sentinel-1 time series. Remote Sensing 2018; 10(8): 1-11. http://dx.doi.org/10.3390/rs10081250.

Brasil. Decreto $n^{\circ}$ 6.514, de 22 de julho de 2008. Diário Oficial da República Federativa do Brasil, Brasília, DF (2008 jul. 23).

Carvalho TS, Domingues EP, Horridge JM. Controlling deforestation in the brazilian amazon: regional economic impacts and land-use change. Land Use Policy 2017; 64: 327-341. http://dx.doi.org/10.1016/j.landusepol.2017.03.001.

Chagas ATA, Costa MA, Martins APV, Resende LC, Kalapothakis E. Illegal hunting and fishing in brazil: A study based on data provided by environmental military police. Natureza \& Conservação 2015; 13(2): 183-189. http://dx.doi.org/10.1016/j.ncon.2015.11.002.

Freitas FLMD, Sparovek G, Mörtberg U, Silveira S, Klug I, Berndes G. Offsetting legal deficits of native vegetation among brazilian landholders: effects on nature protection and socioeconomic development. Land Use Policy 2017; 68 : 189-199. http://dx.doi.org/10.1016/j.landusepol.2017.07.014.

Garrett RD, Koh I, Lambin EF, Waroux YP, Kastens JH, Brown JC. Intensification in agriculture-forest frontiers: land use responses to development and conservation policies in Brazil. Remote Sensing of Environment 2018; 130: $233-243$.

Grecchi RC, Beuchle R, Shimabukuro YE, Aragao L, Arai E, Simonetti D et al. An integrated remote sensing and gis approach for monitoring areas affected by selective logging: A case study in northern mato grosso, brazilian amazon. International Journal of Applied Earth Observation and Geoinformation 2017; 61: 70-80. http:// dx.doi.org/10.1016/j.jag.2017.05.001. PMid:29367838.

Instituto Brasileiro de Geografia e Estatística - IBGE. Informações sobre as cidades e estados do Brasil. Rio de Janeiro: IBGE; 2018 [cited 2018 Nov 18]. Available from: http:// www.cidades.ibge.gov.br/

Instituto Brasileiro do Meio Ambiente e dos Recursos Naturais Renováveis - IBAMA. Fiscalização ambiental. 2018 [cited 2018 Ago 18]. Available from: http://www. ibama.gov.br/index.php?option=com_content\&view=a rticle\&id=825\&Itemid=748\# oquee

Kelly FJ, Fussell JC. Air pollution and public health: emerging hazards and improved understanding of risk. Environmental Geochemistry and Health 2015; 37(4): 631-649. http://dx.doi.org/10.1007/s10653-015-9720-1. PMid:26040976.

Nicolle S, Leroy M. Advocacy coalitions and protected areas creation process: case study in the amazon. Journal of Environmental Management 2017; 198(1): 99-109. http:// dx.doi.org/10.1016/j.jenvman.2017.04.035. PMid:28453991.

Pereira J Fo, Röring LR. Balanço de Massa para Nutrientes Inorgânicos (N e P) no Estuário do Rio Itajaí-Açu, SC. Revista Brasileira de Recursos Hídricos 2016; 21(1): 168187. http://dx.doi.org/10.21168/rbrh.v21n1.p168-187.
Piazza GA, Vibrans AC, Liesenberg V, Oliveira LZD, Moser P. Mapeamento de remanescentes em estágio inicial de sucessão na floresta subtropical atlântica do sul do Brasil. Boletim de Ciências Geodésicas 2016a; 22(4): 774-789. http://dx.doi.org/10.1590/s1982-21702016000400044.

Piazza GA, Vibrans AC, Liesenberg V, Refosco JC. Objectoriented and pixel-based classification approaches to classify tropical successional stages using airborne high-spatial resolution images. GIScience \& Remote Sensing 2016b; 53(2): 206-226. http://dx.doi.org/10.1080/15481603.20 15.1130589 .

Rambusch F, Bender S. A competência da Polícia Militar Ambiental de Santa Catarina para realizar exame pericial ambiental no processo penal. Revista Ordem Pública e Defesa Social 2011; 4(1/2): 1-11.

Reiche J, Hamunyela E, Verbesselt J, Hoekman D, Herold M. Improving near-real time deforestation monitoring in tropical dry forests by combining dense sentinel-1 time series with landsat and alos-2 palsar-2. Remote Sensing of Environment 2018; 204: 147-161. http://dx.doi. org/10.1016/j.rse.2017.10.034.

Rosa RF. Tecnologias da informação aplicadas na PMSC e BPMA [monografia]. Araranguá: Universidade Federal de Santa Catarina; 2015.

Santos CBS, Silva MAM, Souza MFL, Silva DML. Nitrogen distribution in a tropical urbanized estuarine system in northeastern Brazil. Environmental Monitoring and Assessment 2018; 190(2): 68. PMid:29313110.

Schneider LCA, Silva MTD, Agostinetto L, Siegloch AE. Deforestation in mixed ombrophilous forest. Revista Árvore 2018; 42(2): e420206. http://dx.doi.org/10.1590/180690882018000200006 .

Serviço Brasileiro de Apoio às Micros e Pequenas Empresas - SEBRAE. Santa Catarina em números: macrorregião Norte. Florianópolis: Editora Sebrae; 2013. 134 p.

Silva CA Jr, Coutinho AD, Oliveira-Júnior JF, Teodoro PE, Lima M, Shakir M et al. Analysis of the impact on vegetation caused by abrupt deforestation via orbital sensor in the environmental disaster of Mariana, Brazil. Land Use Policy 2018; 76: 10-20. http://dx.doi.org/10.1016/j. landusepol.2018.04.019.

Simonassi JC, Hennemann MC, Talgatti D, Marques NA Jr. Nutrient variations and coastal water quality of Santa Catarina Island, Brazil. Revista Biotemas 2010; 23(1): 1-11.

Sîrbu A, Becker M, Caminiti S, De Baets B, Elen B, Francis $\mathrm{L}$ et al. Participatory patterns in an international air quality monitoring initiative. PLoS One 2015; 10(8): e0136763. http://dx.doi.org/10.1371/journal.pone.0136763. PMid:26313263.

Sothe C, Almeida C, Liesenberg V, Schimalski M. Evaluating Sentinel-2 and Landsat- 8 data to map sucessional forest stages in a subtropical forest in Southern Brazil. Remote Sensing 2017; 9(8): 1-11. http://dx.doi.org/10.3390/rs9080838. 
Sothe C, Goetten LC. Infrações ambientais constatadas pela polícia ambiental no litoral centro-norte de Santa Catarina. Floresta e Ambiente 2017; 24(1): e20150175. http://dx.doi.org/10.1590/2179-8087.017515.

Vibrans AC, McRoberts RE, Moser P, Nicoletti AL. Using satellite image-based maps and ground inventory data to estimate the area of the remaining Atlantic forest in the Brazilian state of Santa Catarina. Remote Sensing of Environment 2013; 130: 87-95. http://dx.doi.org/10.1016/j. rse.2012.10.023.
Warren-Thomas EM, Edwards DP, Bebber DP, Chhang P, Diment AN, Evans TD et al. Protecting tropical forests from the rapid expansion of rubber using carbon payments. Nature Communications 2018; 9(1): 911. http://dx.doi. org/10.1038/s41467-018-03287-9. PMid:29500360.

Watanabe M, Koyama CN, Hayashi M, Nagatani I, Shimada M. Early-stage deforestation detection in the tropics with L-band SAR. IEEE Journal of Selected Topics in Applied Earth Observations and Remote Sensing 2018; 11(6): 2127 2133. http://dx.doi.org/10.1109/JSTARS.2018.2810857. 